\title{
KEDUDUKAN DAN WEWENANG MAHKAMAH KONSTITUSI DALAM SISTEM HUKUM KETATANEGARAAN INDONESIA
}

\author{
NAMA :MUH ASWAL \\ NIM : :10200120137 \\ KELAS :HTN D
}

Abstrak
Kekuasaan kehakiman sesudah amandemen UUD Negara Republik Indonesia Tahun 1945 mengalami perubahan signifikan. UUD Negara Republik Indonesia Tahun 1945 di satu sisi telah mampu memberikan jaminan tentang kebebasan dan kemandirian kekuasaan kehakiman, namun di sisi lain, telah memberikan peluang kepada lembaga lain untuk "mengganggu kebebasan dan kemandirian kekuasaan kehakiman". Kewenangan Mahkamah Konstitusi menjadi kajian tersendiri dari tulisan ini. Sesuai dengan ketentuan Pasal 24C Ayat (1) dan (2) adalah untuk mengadili pada tingkat pertama dan terakhir untuk menguji UU terhadap UUD, memutus sengketa kewenangan lembaga negara yang kewenangannya diberikan UUD, memutus pembubaran partai partai politik, dan memutus perselisihan tentang hasil pemilihan umum. Di samping itu, MK juga wajib memberikan putusan atas pendapat DPR mengenai dugaan pelanggaran oleh presiden dan/atau wakil presiden menurut UUD. Dengan kewenangan tersebut, jelas bahwa MK memiliki hubungan tata kerja dengan semua lembaga negara, yaitu apabila terdapat sengketa antarlembaga negara atau apabila terjadi proses judicial review yang diajukan oleh lembaga kepada MK.

\section{PENDAHULUAN}

Sistem ketatanegaraan pada dasarnya mengandung dua aspek, yaitu aspek yang berkenaan dengan kekuasaan lembaga-lembaga negara beserta hubungannya satu sama lain di antara lembaga-lembaga negara tersebut serta hubungan-hubungan antara lembaga-lembaga negara dengan warga negara. Kedua aspek tersebut dapat dilihat dalam konstitusi suatu negara.1Suatu konstitusi merupakan sebuah sistem hukum, tradisi, dan konvensi yang kemudian membentuk suatu sistem konstitusi atau ketatanegaraan suatu negara. Suatu sistem ketatanegaraan mencerminkan fungsi-fungsi yang terdapat dalam hukum ketatanegaraan. Fungsi-fungsi tersebut di antaranya adalah pembentukan fungsi lembaga, pembagian kewenangan, dan pengaturan batas-batas di antara jabatan satu sama lain, serta hubungan antara jabatan dan warga negara. Ketiga fungsi tersebut, yakni fungsi pembentukan, pembagian, dan pengaturan merupakan fungsi-fungsi mengoperasikan sebuah sistem ketatanegaraan berdasarkan norma-norma, aturan-aturan konstitusi, serta prinsip-prinsip konstitusionalisme dan negara hukum dalam suatu konstitusi.2Fungsi-fungsi tersebut, akan dapat berjalan manakala ketiga kekuasaan yakni legislatif, eksekutif, dan yudikatif dijalankan melalui prinsip pemisahan kekuasaan (separation of power) dan checks and balances.

C.METODE PENELITIAN 
a.ingin tau kewenangan MK

b.Fungsi MK

c.jabatan MK

d.apa kewenangan MK

\section{PEMBAHASAN}

Kedudukan dan Wewenang Mahkamah Konstitusi .... (Nanang Sri Darmadi)669 dari adanya prinsip dan pelaksanaan wewenang untuk menguji atau pengujian peraturan perundang-undangan (judicial review). Di beberapa negara demokrasi pada umumnya, kehadiran sistem pengujian konstitusi diterima sangat baik. Tidak hanya di kalangan akademisi, maupun praktisi bahkan di kalangan kekuasaan peradilan sendiri pun sangat antusias menyambut kehadiran sistem pengujian konstitusi tersebut, karena dengan kehadiran sistem pengujian konstitusi tersebut, dianggap sebagai cara negara hukum modern untuk mengendalikan dan mengimbangi (check and balance) kekuasaan para pejabat pemerintah yang cenderung menjadi sewenang-wenang. Konsep judicial review itu sendiri sebenarnya dilihat sebagai hasil perkembangan modern tentang sistem pemerintahan demokratis yang didasarkan atas ide-ide negara hukum (rule of law), prinsip pemisahan kekuasaan (separation of power), serta perlindungan dan pemajuan hak asasi manusia (the protection of fundamental rights).3Pada dasarnya juicial review hanya dapat dijalankan sebagaimana mestinya dalam negara yang menganut supremasi hukum dan bukan supremasi parlemen. Dalam negara yang menganut sistem supremasi parlemen, produk hukum yang dihasilkan tidak dapat diganggu gugat, karena parlemen merupakan bentuk representasi dari kedaulatan rakyat.4Judicial review atau contitutionalreview di dalamnya terdapat 2 (dua) cakupan tugas pokok yang meliputi : Pertama, menjamin berfungsinya sistem demokrasi dalam hubungan perimbangan peran antara kekuasaan legislatif, eksekutif, dan yudikatif supaya tidak terjadi pemusatan kekuasaan oleh satu cabang kekuasaan terhadap Kedua, melindungi setiap individu warga negara dari penyalahgunaan kekuasaan oleh lembaga negara yang merugikan hak-hak dasar yang dijamin dalam konstitusi.5Di dunia ide pengujian konstitusional berkembang sedemikian luas, penerimaan dan praktik di masing-masing negara tentunya berbeda-beda antara negara yang satu dengan lainnya, yang jelas terus berkembangnya ide pengujian konstitusional tersebut dalam teori dan praktik tidak lepas dari naik turunnya perjalanan sejarah. Tahap-tahap perkembangan tersebut bisa dilihat dalam bentangan waktu yang mana mulai dari gagasan-gagasan tradisional sampai yang paling modern. Di Indonesia, perubahan terhadap Undang-Undang Dasar 1945 memberikan warna baru dalam sistem ketatanegaraan. Salah satu perubahan mendasar dalam Undang-Undang Dasar 1945 adalah SHUXEDKDQ 3DVDO D\DW \DQJEHUEXQ\L z.HGDXODWDQ EHUDGD G Ltangan rakyat dan dilaksanakan menurut Undang-8QGDQJ'DVDU¥Ketentuan ini membawa implikasi bahwa 
kedaulatan rakyat tidak lagi dilakukan sepenuhnya oleh Majelis Permusyawaratan Rakyat, tetapi dilakukan menurut ketentuan Undang-Undang Dasar.6 Selain hal tersebut perubahan Undang-Undang Dasar 1945 telah melahirkan suatu lembaga negara yang berfungsi sebagai pengawal dan penafsir konstitusi, yakni dengan hadirnya Mahkamah Konstitusi. Secara konseptual, gagasan pembentukan Mahkamah Konstitusi adalah untuk menyelenggarakan peradilan guna menegakkan hukum dan keadilan. Mengadili tingkat pertama dan terakhir yang putusannya Kedudukan dan Wewenang Mahkamah Konstitusi .... (Nanang Sri Darmadi)671 bersifat final dalam hal menguji undang-undang terhadap Undang-Undang Dasar 1945, dan kewenangan lain yang dimilikinya.7Dalam Mahkamah Konstitusi inilah, konstitusi dijamin sebagai hukum tertinggi yang dapat ditegakkan sebagaimana mestinya, yang dalam menjalankan fungsinya sebagai pengawal konstitusi, Mahkamah Konstitusi Republik Indonesia dilengkapi dengan lima kewenangan. Empat kewenangannya, yaitu (i) menguji konstitusionalitas undang-undang, (ii) memutus sengketa kewenangan konstitusional antar lembaga negara, (iii) memutus perselisihan hasil pemilihan umum, (iv) memutus pembubaran partai politik, dan satu kewajiban yaitu (v) memutus pendapat Dewan Perwakilan Rakyat tentang tuduhan presiden dan wakil presiden melanggar hukum atau tidak sebagaimana ditentukan dalam Undang-Undang Dasar 1945. Sebagai penafsir tunggal atas konstitusi, Mahkamah Konstitusi dalam perkembangannya oleh sebagian penggiat hukum dikhawatirkan akan menjadi lembaga yang memiliki kewenangan super body. Khususnya dalam menyelesaikan perkara terkait dengan kewenangan yang dimilikinya, Mahkamah Konstitusi secara sepihak bisa menafsirkan Undang-Undang Dasar tanpa dapat dipersoalkan, selain itu putusan yang dihasilkan Mahkamah Konstitusi bersifat final dan mengikat, sehingga ketika ada salah satu pihak yang merasa dirugikan dengan putusan Mahkamah Konstitusi tidak bisa melakukan upaya hukum yang lain. Kewenangan menginterpretasikan konstitusi sebagai pijakan penguji undang-undang oleh hakim konstitusi dirasa sangat begitu besar, sehingga dapat membuka peluang kesewenang-wenangan hakim konstitusi menafsirkan tanpa rasa keadilan terhadap persoalan hukum yang dimohonkan, sehingga berdasarkan kewenangan hakim konstitusi yang sangat besar tersebut, walaupun ada aturan dalam pengujian undang-undang, Mahkamah Konstitusi dapat mengesampingkan rambu-rambu hukum tersebut. Misalkan dalam perkara pengujian Undang-undang Nomor 14 Tahun 1985 Tentang Mahkamah Agung yang dimohonkan oleh seorang hakim Pengadilan Negeri di Padang (Perkara No.004/PUU-I/2003). Mahkamah Konstitusi tercatat pernah menguji perkara tersebut walaupun jelas dalam Pasal 50 Undang-undang Tentang Mahkamah Konstitusi menyatakan bahwa undang-undang yang dapat dimohonkan untuk diuji adalah undang-undang yang diundangkan setelah perubahan Undang-Undang Dasar 1945.8Dalam 
melakukan pemeriksaan perkara di persidangan, kerap kali hakim konstitusi mendapatkan kendala terkait dengan kurang memadainya dokumentasi Dewan Perwakilan Rakyat dalam risalah pembahasan rancangan undang-undang, sehingga menyebabkan hakim konstitusi terhambat memahami konteks pembentukan undang-undang yang berimplikasi pada tidak maksimalnya pengambilan putusan cepat dan tepat seperti keinginan pemohon, karena tidak didukung oleh data yang valid sebagai dasar putusan. Selain hal tersebut di atas, Mahkamah Konstitusi juga belum memiliki pengawasan internal yang baik dalam menjalankan kewenangannya. Mahkamah Konstitusi belum memiliki pengawasan internal yang mampu untuk mendeteksi terjadinya pelanggaran maupun kelemahan organisasi, yang ada hanya mekanisme pengawasan yang bersifat hierarkis struktural dan tidak melibatkan seluruh komponen organisasi sehingga pengawasan tidak partisipatoris dan efektif. Keadaan itu juga diperkuat dengan 8 Refly Harun et al., 2004, Menjaga Denyut Konstitusi, Konstitusi Perss, Jakarta, h. 231.

Kedudukan dan Wewenang Mahkamah Konstitusi .... (Nanang Sri Darmadi)673 gencarnya pemberitaan di media tentang praktik suap terhadap hakim konstitusi yang diduga mampu mempengaruhi putusannya dan menurunkan kewibawaan peradilan di Mahkamah Konstitusi. Sebagaimana dikemukakan oleh Alexander Hamilton bahwa diperlukan ketabahan yang luar biasa bagi para hakim dalam menjalankan tugas mereka sebagai pelindung setia konstitusi, sementara pelanggaran legislatif terhadap konstitusi diawali dengan suara masyarakat mayoritas.9Berdasarkan uraian di atas, maka yang menjadi permasalahan dalam penelitian ini adalah mengenai sejarah pembentukan Mahkamah Konstitusi di Indonesia serta dasar filosofis, yuridis, dan sosiologis tentang kedudukan dan wewenang Mahkamah Konstitusi. B. METODE PENELITIAN Metode pendekatan yang digunakan dalam penelitian ini adalah pendekatan yuridis normatif, karena masalah yang akan diteliti ada hubungannya dengan sejarah pembentukan MahkamahKonstitusi dan dasar filosofis, yuridis, maupun sosiologis tentang kedudukan dan wewenang Mahkamah Konstitusi dalam sistem hukum ketatanegaraan Indonesia. Spesifikasi penelitian ini bersifat deskriptif analisis, karena diharapkan mampu memberi gambaran secara rinci, sistematis, dan menyeluruh dengan obyek yang akan diteliti, yakni kaitannya dengan kedudukan dan wewenang Mahkamah Konstitusi. Data yang digunakan dalam penelitian ini adalah data sekunder, yaitu data yang diperoleh dari bahan-bahan pustaka.Data yang diperoleh dalam penelitian, kemudian akan dianalisis secara kualitatif, yaitu data yang diperoleh kemudian akan disusun secara sistematis yang selanjutnya akan dianalisis secara kualitatif untuk 9 Leonard W. mencapai kejelasan mengenai kedudukan dan wewenang Mahkamah Konstitusi dalam sistem hukum ketatanegaraan Indonesia. C. HASIL DAN PEMBAHASAN Sejarah Pembentukan Mahkamah Konstitusi di Indonesia Pelaksanaan judicial review 
yang dipelopori oleh John Marshall memberikan pengaruh yang sangat penting bagi negara lain di dunia, termasuk di Indonesia dengan berdirinya Mahkamah Konstitusi Indonesia. Alhasil, kehidupan ketatanegaraan Indonesia mengalami perubahan mendasar, yakni ketika dimulainya perubahan Undang-Undang Dasar 1945 pada tahun 1999. Perubahan Undang-Undang Dasar 1945 menjadi catatan sejarah ketatanegaraan Indonesia, karena fondasi ketatanegaraan mengalami perubahan drastis, hampir meliputi berbagai bidang kehidupan.Sejak tahun 2001, secara resmi Amandemen Ketiga Undang-Undang Dasar 1945 (melalui Sidang Tahunan Majelis Permusyawaratan Rakyat Tahun 2001) menerima masuknya Mahkamah Konstitusi di dalam Undang-Undang Dasar tersebut.10Pembentukan Mahkamah Konstitusi menandai era baru dalam sistem kekuasaan kehakiman di Indonesia. Beberapa wilayah yang tadinya tidak tersentuh (untouchable) oleh hukum, seperti masalah judicial review terhadap undang-undang, sekarang dapat dilakukan oleh Mahkamah Kontitusi.11Majelis Permusyawaratan Rakyat melakukan perubahan yang fundamental terhadap Pasal 24 Undang-Undang Dasar 1945 dengan cara mengubah Pasal 24 dan menambahnya dengan Pasal 24A, Pasal 24B, dan Pasal 24C yang di dalamnya memuat dua lembaga baru, yaitu Mahkamah Konstitusi dan Komisi Yudisial. Kedudukan dan Wewenang Mahkamah Konstitusi .... (Nanang Sri Darmadi)675 Indonesia merupakan negara ke-78 yang membentuk Mahkamah Konstitusi. Pembentukan Mahkamah Konstitusi sendiri merupakan fenomena negara modern abad ke-20,12 tatkala Perubahan Ketiga Undang-Undang Dasar Negara Republik Indonesia, berdasarkan Pasal 24 ayat (2) Tahun 1945 juncto Pasal 24C Undang-Undang Dasar Negara Republik Indonesia, diputuskan dalam Rapat Paripurna Majelis Permusyawaratan Rakyat Republik Indonesia.13Pemikiran mengenai pentingnya suatu Mahkamah Konstitusi telah muncul dalam sejarah ketatanegaraan Indonesia sebelum merdeka. Pada saat pembahasan rancangan Undang-Undang Dasar di Badan Penyelidik Usaha-usaha Persiapan Kemerdekaan Indonesia (BPUPKI). Ide perlunya judicial review, khususnya pengujian undang-undang terhadap Undang-Undang Dasar, kembali muncul pada saat pembahasan Rancangan Undang-undang Kekuasaan Kehakiman yang selanjutnya ditetapkan menjadi Undang-undang Nomor 14 Tahun 1970 Tentang Pokok-Pokok Kekuasaan Kehakiman.Pada saat pembahasan perubahan Undang-Undang Dasar 1945 dalam era reformasi, pendapat mengenai pentingnya Mahkamah Konstitusi muncul kembali. Perubahan Undang-Undang Dasar 1945 yang terjadi dalam era reformasi tersebut telah menyebabkan Majelis Permusyawaratan Rakyat tidak lagi berkedudukan sebagai lembaga tertinggi negara dan supremasi, tetapi beralih dari supremasi Majelis Permusyawaratan Rakyat kepada supremasi konstitusi.Perubahan yang mendasar tersebut perlu adanya mekanisme institusional dan konstitusional serta hadirnya lembaga negara yang mengatasi kemungkinan sengketa antar lembaga negara yang kini 12 
Mahkamah Konstitusi Republik Indonesia, 2010, Hukum Acara Mahkamah Konstitusi, Sekretariat Jenderal dan Kepaniteraan Mahkamah Konstitusi, telah menjadi sederajat serta saling mengimbangi dan saling mengendalikan (checks and balances). Kehadiran Mahkamah Konstitusi melalui perubahan ketiga Undang-Undang Dasar 1945 dalam sidang tahunan Majelis Permusyawaratan Rakyat (2001) memiliki dasar konstitusional yang kuat. Artinya, eksistensi, kedudukan, kewenangan, kewajiban, dan komposisi para hakim Mahkamah Konstitusi diatur dengan tegas dalam Undang-Undang Dasar 1945. Namun, dengan disahkannya Perubahan Ketiga Undang-Undang Dasar 1945, tidak dengan sendirinya Mahkamah Konstitusi telah terbentuk. Untuk mengatasi kekosongan tersebut pada Perubahan Keempat Undang-Undang Dasar 1945 ditentukan dalam Aturan Peralihan Pasal bahwa Mahkamah Konstitusi paling lambat sudah harus terbentuk pada 17 Agustus 2003. Sebelum terbentuk, segala kewenangan Mahkamah Konstitusi dilakukan oleh Mahkamah Agung. Undang-undang Mahkamah Konstitusi, yaitu Undang-undang Nomor 24 Tahun 2003 disahkan pada 13 Agustus 2003. Waktu pengesahan Undang-undang Nomor 24 Tahun 2003 Tentang Mahkamah Konstitusi inilah yang ditetapkan sebagai hari lahirnya Mahkamah Konstitusi. Berdasarkan Undang-undang Mahkamah Konstitusi, pembentukan Mahkamah Konstitusi segera dilakukan melalui rekrutmen hakim konstitusi oleh tiga lembaga negara, yaitu Dewan Perwakilan Rakyat, presiden, dan Mahkamah Agung. Setelah melalui tahapan seleksi sesuai mekanisme yang berlaku pada masing-masing lembaga, akhirnya Dewan Perwakilan Rakyat, presiden, dan Mahkamah Agung menetapkan masing-masing tiga calon hakim konstitusi. Selanjutnya ditetapkan oleh presiden sebagai hakim konstitusi. sembilan hakim konstitusi pertama ditetapkan pada 15 Agustus 2003 dengan Keputusan Presiden Nomor 147/M Tahun 2003. Pengucapan Sebagai lembaga penafsir tunggal konstitusi, banyak hal dalam mengadili menimbulkan akibat terhadap kekuasaan lain dalam kedudukan berhadap-hadapan, terutama terhadap lembaga legislatif di mana produknya direview. Kedudukan Mahkamah Konstitusi dalam sistem ketatanegaraan Indonesia adalah sebagai lembaga negara yang menjalankan fungsi yudisial dengan kompetensi obyek perkara ketatanegaraan. Keberadaan Mahkamah Konstitusi dipahami sebagai pengawal konstitusi untuk memperkuat dasar-dasar konstitusionalisme dalam Undang-Undang Dasar 1945. Oleh karena itu, Mahkamah Konstitusi mempunyai kewenangan dengan batasan yang jelas sebagai bentuk penghormatan atas konstitusionalisme. Batas-batas kewenangan yang dimiliki oleh Mahkamah Konstitusi sebagai salah satu lembaga yudisial merupakan bentuk terselenggaranya sistem perimbangan kekuasaan di antara lembaga negara (checks and balances). Mahkamah Konstitusi sebagai salah satu pelaku kekuasaan kehakiman diharapkan mampu mengembalikan citra lembaga peradilan di Indonesia sebagai kekuasaan kehakiman yang merdeka yang dapat dipercaya dalam menegakkan hukum dan keadilan. Dasar filosofis dari 
wewenang dan kewajiban Mahkamah Konstitusi adalah keadilan substantif dan prinsip-prinsip good governance. Selain itu, teori-teori hukum juga memperkuat keberadaan Mahkamah Konstitusi sebagai lembaga negara pengawal dan penafsir konstitusi. Kehadiran Mahkamah Konstitusi beserta segenap wewenang dan kewajibannya, dinilai telah merubah doktrin Kedudukan dan Wewenang Mahkamah Konstitusi .... (Nanang Sri Darmadi)679 supremasi parlemen (parliamentary supremacy) dan menggantikan dengan ajaran supremasi konstitusi.16Keadilan substantif/keadilan materiil (substantive justice) merupakan al qist atau bagian yang wajar dan patut, tidak mengarahkan kepada persamaan, melainkan bagian yang patut, berpihak kepada yang benar. Dalam penerappan keadilan substantif ini, pihak yang benar akan mendapat kemenangan sesuai dengan bukti-bukti akan kebenarannya. Teori-teori yang menjadi dasar pentingnya reformasi konstitusi dan menjadi dasar wewenang serta kewajibah Mahkamah Konstitusi adalah teori kedaulatan negara, teori konstitusi, teori negara hukum demokrasi, teori kesejahteraan, teori keadilan, dan teori kepastian hukum. Dasar yuridis wewenang Mahkamah Konstitusi berasal dari Undang-Undang Dasar 1945 yang diatur dalam Pasal 7A, Pasal 78, dan Pasal 24C dan dijabarkan dengan Undang-undang Nomor 24 Tahun 2003. Terhadap perorangan, kesatuan masyarakat adat sepanjang masih hidup, badan hukum publik atau privat, lembaga negara, partai politik, ataupun pemerintah dan Dewan Perwakilan Rakyat, jika hak dan/atau wewenang konstitusionalnya dirugikan, dapat mengajukan permohonan ke Mahkamah Konstitusi.Mahkamah Konstitusi merupakan lembaga negara yang baru dalam sistem ketatanegaraan Indonesia hasil perubahan Undang-Undang Dasar Negara Republik Indonesia Tahun 1945 yang dibentuk karena buruknya penyelenggaraan negara terutama pada masa orde baru, yang ditandai dengan maraknya korupsi, kolusi, dan nepotisme, markus (makelar kasus) sampai saat ini, dan dicampakkannya nilai-nilai keadilan hukum menjadi faktor yang dalam melakukan perubahan diberbagai bidang, terutama sistem peradilan.17Sebagai organ konstitusi, Mahkamah Konstitusi didesain untuk menjadi pengawal dan penafsir undang-undang dasar melalui putusan-putusannya. Dalam menjalankan tugas konstitusionalnya, Mahkamah Konstitusi berupaya mewujudkan visi kelembagaannya, yakni tegaknya konstitusi dalam rangka mewujudkan cita negara hukum dan demokrasi demi kehidupan kebangsaan dan kenegaraan yang bermartabat. Visi tersebut menjadi pedoman bagi Mahkamah Konstitusi dalam menjalankan kekuasaan kehakiman yang diembannya secara merdeka dan bertanggung jawab sesuai dengan amanat Undang-Undang Dasar Negara Republik Indonesia Tahun 1945. Mahkamah Konstitusi membuka diri untuk menerima permohonan dari masyarakat yang merasa hak-haknya dan kewenangan konstitusionalnya dilanggar akibat berlakunya suatu undang-undang. D. SIMPULAN DAN SARAN Simpulan Sejarah pembentukan 
Mahkamah Konstitusi di Indonesia tidak terlepas dari perkembangan judicial review yang terjadi dibeberapa negara di dunia. Perkembangan judicial review yang paling berpengaruh terhadap keberadaan Mahkamah Konstitusi adalah pada saat Pelaksanaan judicial review yang dipelopori oleh John Marshall dalam kasus Marbury versus Madison. Pemikiran mengenai pentingnya suatu Mahkamah Konstitusi telah muncul dalam sejarah ketatanegaraan Indonesia sebelum 17 Indra Perwira, dkk Kedudukan dan Wewenang Mahkamah Konstitusi. (Nanang Sri Darmadi)681 merdeka. Pada saat pembahasan rancangan Undang-Undang Dasar di Badan Penyelidik Usaha-usaha Persiapan Kemerdekaan Indonesia, kemudian ide perlunya judicial review kembali muncul pada saat pembahasan Rancangan Undang-undang Kekuasaan Kehakiman (Undang-undang Nomor 14 Tahun 1970). Pada saat pembahasan perubahan Undang-Undang Dasar 1945 dalam era reformasi, pendapat mengenai pentingnya Mahkamah Konstitusi muncul kembali. Pada akhirnya, dengan Amandemen Ketiga Undang-Undang Dasar 1945 yang dilakukan oleh Majelis Permusyawaratan Rakyat lahirlah sebuah lembaga negara baru, yakni Mahkamah Konstitusi, yang berfungsi sebagai penjaga konstitusi (the guardian of constitution) dan juga berperan sebagai penafsir konstitusi (the interpreter of constitution). Eksistensi Mahkamah Konstitusi terwujud dalam melaksanakan tugas dan kewenangannya setelah Dewan Perwakilan Rakyat dan pemerintah menyetujui diundangkannya Undang-undang Nomor 24 Tahun 2003 Tentang Mahkamah Konstitusi sebagai dasar pijak Mahkamah Konstitusi dalam penyelenggaraan pengujian konstusionalitas sesuai amanat Undang-Undang Dasar 1945. Kedudukan Mahkamah Konstitusi dalam sistem ketatanegaraan Indonesia merupakan bagian dari kekuasaan kehakiman dan memiliki posisi sejajar dengan Mahkamah Agung. Mahkamah Konstitusi memiliki empat kewenangan dan satu kewajiban konstitusional, yaitu menguji undang-undang terhadap undang-undang dasar, memutus sengketa kewenangan lembaga negara yang kewenangannya diberikan oleh undang-undang dasar, memutus pembubaran partai politik; dan memutus perselisihan tentang hasil pemilihan umum. Satu kewajiban konstitusional Mahkamah Konstitusi, yakni memberikan putusan atas pendapat Dewan Perwakilan Rakyat mengenai dugaan pelanggaran oleh presiden/dan atau wakil presiden menurut Undang-Undang Dasar. Judicial review oleh Mahkamah Konstitusi sebagai kontrol antar lembaga-lembaga negara untuk terwujudnya cita negara hukum yang demokratis. Dalam melaksanakan kewenangannya, Mahkamah Konstitusi telah menegaskan dirinya sebagai lembaga negara pengawal demokrasi dengan menjunjung prinsip peradilan yang menegakkan keadilan substantif dalam setiap putusannya. Keadilan di sini menjadi dasar filosofis pelaksanaan kewenangan Mahkamah Konstitusi. Selain keadilan substantif, sebagai dasar filosofis dalam menjalankan kewenangan dan kewajibannya seperti yang diamanatkan oleh Undang-Undang Dasar 1945, Mahkamah Konstitusi sebagai lembaga peradilan menerapkan prinsip keterbukaan dan 
transparansi (openness and transparency), serta akuntabilitas kepada publik. Keberadaan Mahkamah Konstitusi ini juga tidak terlepas dari teori-teori hukum, antara lain teori kedaulatan, teori konstitusi, teori negara hukum demokrasi, teori kesejahteraan, teori keadilan, dan teori kepastian hukum. Dasar yuridis kewenangan Mahkamah Konstitusi menguji undang-undang diatur dalam Pasal 24C ayat (1) Undang-Undang Dasar 1945 yang pada intinya menyatakan bahwa Mahkamah Konstitusi berwenang menguji undang-undang terhadap Undang-Undang Dasar. Pada tahap akhir, dengan disahkannya Undang-undang Nomor 24 Tahun 2003, maka Mahkamah Konstitusi telah resmi dalam melaksanakan kewenangannya yang diberikan oleh Undang-Undang Dasar 1945. Keberadaan Mahkamah Konstitusi dengan kewenangan yang dimilikinya, terpicu dengan buruknya penyelenggaraan negara terutama saat masa orde baru yang ditandai dengan maraknya Kedudukan dan Wewenang Mahkamah Konstitusi .... (Nanang Sri Darmadi)683 korupsi, kolusi, dan nepotisme, markus (makelar kasus), dicampakkannya nilai-nilai keadilan hukum, serta hak-hak konstitusional warga negara yang dilanggar. Saran Keberadaan Mahkamah Konstitusi dalam kehidupan ketatanegaraan sangat penting dalam melindungi dan mengemban suara rakyat. Dengan putusan-putusannya, Mahkamah Konstitusi merupakan jawaban konkrit atas segenap permasalahan yang terjadi di tengah-tengah masyarakat terhadap perundang-undangan yang dinilai warga bertentangan dengan konstitusi. Tudingan adanya hakim tidak bersih di Mahkamah Konstitusi, dapat mencoreng citra Mahkamah Konstitusi, sehingga diperlukan komunikasi di antara para hakim konstitusi dan pengawasan baik internal maupun eksternal di Mahkamah Konstitusi. Hal itu penting karena membiarkan Mahkamah Konstitusi sebagai lembaga peradilan tanpa pengawasan akan membahayakan. Putusan Mahkamah Konstitusi terhadap suatu perkara, tidak jarang menimbulkan pro dan kontra. Keputusan Mahkamah Konstitusi adalah keputusan final dan mengikat yang harus dihormati. Namun, tentu hakim Mahkamah Konstitusi tidak selalu sempurna. Sudah pasti ada sejumlah hal yang membuat seorang hakim Mahkamah Konstitusi menjadi kurang teliti dalam mengambil keputusan. Selain itu, tidak ada jaminan seratus persen hakim Mahkamah Konstitusi selalu bersih dan kuat menghadapi cobaan suap. Oleh karena itu, untuk mengawasi dan menindak hakim Mahkamah Konstitusi yang diduga memberikan keputusan yang tidak obyektif atau melanggar kode etik, perlu segera dibentuk Badan Kehormatan Hakim untuk menindaklanjuti kasus pelanggaran kode etik. Dengan demikian, putusan hakim Mahkamah 684 Jurnal Hukum Vol XXVI, No. 2, Agustus 2011 Konstitusi dapat diuji keobyektifitasannya dan tidak merugikan pihak tertentu. Dari awal berdirinya, Mahkamah Konstitusi sejak tahun 2003 sampai dengan tahun 2009 telah melaksanakan persidangan dari 404 perkara yang masuk ke bagian registrasi perkara, sebagaimana dalam Laporan Tahunan 2009 Mahkamah Konstitusi. Banyaknya perkara yang masuk ke Mahkamah Konstitusi dari berbagai 
daerah perlu dilakukan pendistribusian untuk penanganan perkara tersebut. Dibentuknya perwalian di daerah-daerah di wilayah tertentu, bisa menjadi jalan keluar agar perkara yang masuk ke Mahkamah Konstitusi cepat terselesaikan dan memenuhi asas peradilan yang cepat, sederhana, dan murah.

\section{KESIMPULAN}

Berdasarkan Pasal 24C ayat (1) UUD 1945 yang ditegaskan kembali dalam Pasal 10 ayat (1) huruf a sampai dengan d UU 24/2003, kewenangan Mahkamah Konstitusi adalah menguji undang-undang terhadap UUD 1945; memutus sengketa kewenangan lembaga negara yang kewenangannya diberikan oleh UUD 1945; memutus pembubaran partai.

\section{REFRENSI}

Buku : A.Kosasih Djahiri, 1971, Ilmu Politik, Parmaco, Bandung. Abdul Mukthie Fadjar, 2006, Hukum Konstitusi \& Mahkamah Konstitusi, Konstitusi Press Jakarta dan Citra Media Yogyakarta.

Abdul Rasyid Thalib, 2006, Wewenang Konstitusi dan Implikasinya dalam Sistem Ketatanegaraan Republik Indonesia, Citra Aditya Bakti, Bandung. Abu Daud Busroh dan Abu Bakar Busroh, 1991, Azas-azas Hukum Tata Negara, Ghalia Indonesia, Jakarta.

Ahmad Syahrizal, 2006, Peradilan Konstitusi, Suatu Studi tentang Adjudikasi Konstitusional Sebagai Mekanisme Penyelesaian Sengketa Normatif, Pradnya Paramita, Jakarta.

Bagir Manan, 1995, Empat Tulisan Tentang Hukum, Program Pascasarjana BKU Hukum Ketatanegaraan, Universitas Padjajaran, Bandung. Bambang Sutiyoso, 2009, Tata Cara Penyelesaian Sengketa di Lingkungan Mahkamah Konstitusi, UII Press, Yogyakarta.

C.F. Strong, 2004, Konstitusi-konstitusi Politik Modern, Kajian Tentang Sejarah \& Bentuk-bentuk Konstitusi Dunia, Nuansa dan Nusamedia, Bandung.

C.S.T Kansil dan Christine S.T. Kansil, 2010, Perbandingan Hukum Administrasi Negara, Rineka Cipta, Jakarta. Dahlan Thaib, 2009, Ketatanegaraan Indonesia, Perspektif Konstitusional, Total Media, Yogyakarta. , 2005, Teori dan Hukum Konstitusi, Raja Grafindo Persada, Jakarta. Emeritus John Gilissen dan Emeritus Frits Gorle, 2009, Sejarah Hukum, Suatu Pengantar, Refika Aditama, Bandung. G.S.Diponolo, 1975, IImu Negara, Balai Pustaka, Jakarta.

loanes Rakhmat, 2009, Sokrates Dalam Tetralogi Plato, Sebuah Pengantar dan Terjemahan Teks, Gramedia Pustaka Utama, jakarta.

Iriyanto A.Baso Ence, 2008, Negara Hukum \& Hak Uji Konstitusionalitas Mahkamah Konstitusi, Telaah Terhadap Kewenangan Mahkamah Konstitusi, Alumni, Bandung. Ismail Sunny, 1986, Pergeseran Kekuasaan Eksekutif, Aksara Baru, Jakarta. 